\title{
Fungsi komunikasi korporat Humas PT. Perkebunan Nusantara V Pekanbaru
}

\author{
Rosmala \\ STISIP Persada Bunda, Pekanbaru, Indonesia
}

\begin{abstract}
ABSTRAK
Salah satu perusahan besar yang bergerak dibidang perkebunan kelapa sawit dan karet kerap sering diberitakan dengan berbagai isu terkait dengan pemerintah, masyarakat maupun investor adalah PT. Perkebunan Nusantara V(PTPN V). Keberadaan suatu isu yang ada di perusahaan perlu ditanggapi dengan bijak oleh Humas sebagai bagian dari tugas nya adalah melaksanakan fungsi komunikasi korporat untuk reputasi perusahaan. Penelitian ini bertujuan untuk mengetahui fungsi komunikasi, hambatan, dan solusi komunikasi korporat oleh Humas PTPN V Pekanbaru. Adapun penelitian ini menggunakan metode kualitatif dengan jenis analisis data berupa deskriptif. Hasil penelitian menunjukkan bahwa fungsi komunikasi korporat oleh humas PTPN V sudah terlaksana sesuai dengan fungsi manajemen dalam perusahaan melalui upaya membangun dan mempertahankan identitas, citra dan reputasi; CSR; media; krisis komunikasi; komunikasi pemasaran; hubungan dengan investor; hubungan terhadap pemerintah;dan sistem komunikasi internal. Namun, ada beberapa fungsi komunikasi korporat yang penting untuk ditingkatkan seperti dalam konteks komunikasi pemasaran, hubungan media, hubungan pemerintah dan komunikasi internal. Sedangkan hambatan pada komunikasi korporat yang dihadapi oleh humas PTPN V yaitu pada penanganan isu manajemen dan krisis komunikasi. Solusi untuk mengatasi hambatan tersebut dengan menyelesaikan masalah isu manajemen di PTPN V secara internal maupun ekternal publik. Simpulan penelitian menunjukkan bahwa humas PTPN V mampu mewujudkan hubungan lebih baik dengan pemerintah, media, mencegah isu dan krisis manajemen sedini mungkin sehingga dapat meningkatkan dan mempertahankan kemampuan komunikasi korporat dalam membangun kepercayaan serta efek positif untuk keberlanjutan perusahaan.
\end{abstract}

Kata-kata Kunci: Komunikasi korporat; humas; fungsi komunikasi; PTPN V; citra

\section{Public Relations Corporate Communications Function of PT. Perkebunan Nusantara V Pekanbaru}

\begin{abstract}
One of the large companies engaged in oil palm and rubber plantations, often reported with various issues related to the government, society and investors, is PT Perkebunan Nusantara V (PTPN V). The company's issue needs to be addressed wisely by Public Relations as part of its duty to carry out corporate communication functions in maintaining its reputation. This study aims to determine the communication function, barriers, and corporate communication solutions by Public Relations of PTPN V Pekanbaru. This research uses qualitative methods with a descriptive type of data analysis. The results show that the corporate communication function implementation by public relations of PTPN V is following the management function in the company through efforts to build and maintain identity, image, and reputation; CSR; media; crisis communication; marketing communications; investor relations; relations with the government, and internal communication systems. However, several corporate communication functions are essential to improve, such as in the context of marketing communications, media relations, government relations, and internal communications. Meanwhile, the barriers to corporate communication faced by PTPN V's public relations are handling management issues and communication crises. The solution to overcome these obstacles is by solving management issues in PTPN V internally and externally through its public. The research conclusions show that PTPN V's public relations can achieve better relations with the government and media while preventing issues and manage crises as early as possible to improve and maintain corporate communication skills in building trust and positive effects for the company's sustainability.
\end{abstract}

Keywords: Corporate communication; public relations; communication function; PTPN V; imagery

Korespondensi: Rosmala S.Sos., M.Si. STISIP Persada Bunda. Jl.Dipenogoro No. 42 Pekanbaru Kota 28156.Email:rosmala.1bs@gmail.com

Submitted: June 2020, Accepted: September 2020, Published: February 2021

ISSN: 2528-6927 (printed), ISSN: 2541-3678 (online). Website: http://jurnal.unpad.ac.id/profesi-humas 


\section{PENDAHULUAN}

Komunikasi korporat sangat penting bagi perusahaan karena komunikasi korporat merupakan tiang pondasi untuk mempertahankan perusahaan baik secara internal publik atau ekternal publik. Fungsi komunikasi korporat bagi Humas PT. Perkebunan Nusantara V dapat terlihat dari struktur komunikasi integratif yang dapat menghubungkan pada pemilik kepentingan kepada perusahaan. Struktur komunikasi yang integratif merupakan sebuah sistem komunikasi yang memungkinkan perusahaan untuk mengatur segala bentuk jenis komunikasi secara strategis. Selanjutnya PTPN V adalah salah satu perusahan BUMN (Badan Usaha Milik Negara) perusahaan ini bergerak tumbuh dan berkembang di bisnis kelapa sawit dan karet dengan tujuan utamanya melayani kepentingan umum/publik kemudian asal modal usaha dari pemerintah. Selanjutnya PTPN V merupakan perusahaan besar yang kerap sering diberitakan dengan berbagai isu terkait mitra baik dengan pemerintah, masyarakat maupun investor.

Fenomena pertama, sebagaimana diberitakan pada bulan Juli 2019, PTPN V Riau bertanggungjawab terhadap kebun sawit dan karet di sejumlah kabupaten/kota di Riau yang berjumlah 19 lokasi saat ini. Kemudian perusahaan juga memiliki kebun inti dan plasmanya tidak produktif atau membuahkan sawit lagi dikarenakan pohon sawit sudah berusia tua saat ini. Dampak kondisi ini sebagian besar para petani plasma, tidak bersedia lagi untuk bermitra dan kerjasama dengan PTPN V disebabkan tidak dilakukannya pembinaan petani juga merasa dirugikan.Untuk memenuhi pasokan tandan buah segar di Pabrik Kelapa Sawit (PKS) nya sehingga jumlah TBS dari luar masuk ke pabrik antara lain di PKS Sei 1Pagar (Aznil, 2019).

Fenomena kedua, pada tahun yang sama muncul pemberitaan PTPN V Sei Rokan telah melakukan pengusiran dan melakukan pemaksaan kepada BHL atau Buruh Harian Lepas nya dari rumah yang mereka huni di kepemilikan perusahaan perkebunan sawit. Para petugas seperti Asisten Kepala Kebun, Asisten Umun, TNI, Polisi, Satpam, dihimbaukan untuk mengusir para buruh yang ada diperkebunan untuk segera mengosongkan rumah yang mereka tempati saat ini perumahan PTPN V. Akibat pemberitaan ini muncul permasalahan antara karyawan dengan perusahaan (Hadi \& Kuswanto, 2019).

Fenomena ketiga, PTPN V juga mengalami permasalahan dengan pemerintah terkait penggugatan eksekusi lahan oleh LSM Riau Madani. Pada akhirnya secara resmi PTPN pengembalian lahan yang luasnya lebih kurang 2.800 hektar kepada pemerintah. Lahan 
tersebut akan diserahkan kepada masyarakat di desa senama nenek, Kabupaten Kampar, Riau (Siregar, 2019). Pemberitaan ini masih berlanjut dan semakin memanas yang dianggap sangat penting dan menarik perhatian masyarakat. Hal ini pun didukung dengan media massa secara serempak terus-menerus menayangkan, menulis dan memposting pemberitaan ini. Hal ini tentunya humas harus cepat dan tanggap mengatasi masalah yang melibatkan pihak pemerintah dan media.

Fenomena keempat, adanya komitmen baru oleh PTPN V untuk menekan jumlah emisi gas dalam upaya meraih target standar ISCC yaitu International Sustainability \& Carbon Certification sampai dengan $100 \%$ kemudian ini bisa terwujud melalui hasil dari seluruh rangkaian kegiatan produksi perkebunan kelapa sawit (Humas PTPN V, 2019).

Untuk menyikapi fenomena dan permasalahan isu yang terjadi, humas berperan aktif dalam kegiatan fungsi komunikasi korporat di PTPN V yang terdiri dari: identitas, citra, reputasi; CSR; hubungan media; komunikasi pemasaran;komunikasi internal simtem; hubungan pemerintah; hubungan investor; komunikasi krisis. Hal tersebut sejalan dengan penelitian Juwita mengenai strategi komunikasi korporat yang menjelaskan bahwa didalam perkembangan dan kemajuan media interaktif digital sudah membawa struktur komunikasi baru sehingga sangat penting bagi para praktisi dan akademisi komunikasi korporat untuk memahami perubahan yang disebabkan oleh perkembangan akan hal tersebut (Juwita, 2017). Berbagai usaha dilakukan untuk meningkatkan kinerjanya di PTPN V antara lain adanya peningkatkan kualitas dan kuantitas CPO (hasil olah minyak sawit), palm kernel oil ,ribbd smoked sheet (RSS), inti sawit, pada standar Indonesia rubber sir 10/20.Jika produksi yang dihasilkan berdasarkan standar nasional dan internasional harapannya penjualan komoditi dan dipasarkan menambah nilai keuntungan bagi perusahaan. Selanjutnya PTPN $\mathrm{V}$ dalam meningkatkan kualitas efesiensi dan efektifitas dikeseluruhan lini produksi termasuk didalamnya antara lain adanya kegiatan pembukaan lahan, penanaman ulang dikebun, melakukan kegiatan terkait pengembangan kebun plasma. adanya pengolahan lahan yang baru, terlaksanya pemeliharaan, dan melakukan pembibitan yang bertap serta berkelanjutan.

PTPN V dikenal sebagai perusahan bisnis yang besar khususnya di wilayah provinsi Riau. eksistensi perusahaan selalu berusaha maksimal mewujudkan menjaga kesinambungan operasional agar dapat memberikan manfaat yang optimal bagi para pemegang saham (shareholder) maupun pemegang saham. Kunci terpenting manajemen dalam pengelolaan perusahaan adalah adanya 
komitmen yang dibangun. Salah satu usaha yang dilakukan perusahan adalah selalu mengikuti perkembangan roundtable on sustainable palm oil, aktif di konferensi minyak sawit lestari,senantiasa menjaga keharmonisan, keselarasan terhadap lingkungan internal dan eksternal perusahan seperti karyawan, investor/pemasok, seluruh konsumen, seluruh masyarakat di sekitar lingkungan ekologi dan lain-lain.

Secara teknik istilah komunikasi korporat diartikan sebagai kemampuan dalam menunjukkan kepribadian dan identitas stakeholders perusahaan kepada publik. Sedangkan tujuan komunikasi korporat dalam suatu perusahan adalah sebagai alat penghubung untuk mencapai visi dan misi perusahan dengan menggunakan strategi manajemen, melakukan penyebaran informasi meningkatkan sistem fungsi komunikasi korporat dengan tepat sasaran. Menurut Wasesa dan Jim, corporate communcations yaitu komunikasi dua arah yang asimetris dilakukan dengan komunikasi jujur dua arah saling memberi dan saling menerima tujuannya mempersuasi/membujuk audiensi misalnya untuk mengubah sikap pembelian barang dan jasa,mengadaptasi hidup sehat, dan lain-lain. Dari uraian tersebut dapat diartikan bahwa komunikasi korporat merupakan sarana untuk pengiriman pesan yang dilakukan perusahaan terhadap publik (Wasesa \& Jim,
2010).

Dalam literatur lainnya menyebutkan bahwa komunikasi korporat merupakan suatu cara organisasi untuk berkomunikasi dengan bermacam kelompok orang. Komunikasi korporat dapat diartikan sebagai cara untuk membangun komunikasi dalam organisasi dimana komunikasi korporat menghubungkan antara aplikasi teori komunikasi yang membuat hubungan komunikasi korporat dan strategi perusahaan secara keseluruhan (Argenti, 2010). Definisi lainnya, menyebutkan bahwa komunikasi korporat mencakup komunikasi pemasaran, komunikasi organisasi, dan komunikasi manajemen. Asal kata komunikasi korporat mengadopsi sudut pandang "korporat" yaitu berasal dari bahasa latin "corpus" yang berarti "tubuh" atau "keseluruhan". Oleh karena itu, komunikasi perusahaan membahas mengenai pemenuhan tujuan organisasi (Van Riel \& Fombrun, 2019).

Humas merupakan tenaga ahli yang berpengalaman dan memiliki kemampuan yang tinggi dalam mengatasi hambatan dan mampu memberikan solusi sebagai upaya penyelesaian masalah di internal ataupun eksternal perusahaan. Humas juga dianggap sebagai fasilitator pemecahan masalah yang dapat membantu pimpinan serta sekaligus menjadi penasehat saat perusahaan mengalami krisis komunikasi. Selanjutanya, humas juga 
diartikan sebagai pakar teknisi komunikasi yang mampu menguasai komunikasi dua arah dalam mempertimbangkan reputasi dan citra perusahan.

Humas bertugas menjadi penghubung yang jujur serta memberi saran kepada manajemen secara tegas, akurat, identifikasi data lengkap dan tidak ada yang perlu ditutup-tutupi/ merahasiakan namun hal ini dapat dilaksanakan apabila humas memiliki akses menuju pimpinan perusahan (Nova, 2011). Humas dituntut untuk bisa kreatif dan inovatif selalu transparan dalam menyampaikan informasi perusahan, menyehatkan mutu profesi pengetahuan serta dedikasi yang tinggi pada korporat/perusahaan, kenyataannya apa yang terjadi dengan PTPN $\mathrm{V}$ dengan fenomena yang terjadi membuat beberapa harapan tidak tercapai secara maksimal karena kenyataan yang ada seperti sengketa permasalahan dengan pemerintah, media, komunikasi internal, dan komunikasi, pemasaran. Hal ini bagi humas menjadi tantangan yang harus mampu mewujudkan agar tidak ada lagi kesenjangan di PTPN terutama dalam melaksanakan fungsi komunikasi korporat. Adapun bentuk komunikasi yang dibangun oleh humas bisa melalui media internal dan eksternal publik sehingga bisa kondusif serta menciptakan peningkatan kerja perusahaan. Visi dan misi perusahaan dapat tercapai sehingga keberlangsungan perusahaan dimasa mendatang dapat nilai peningkatan yang berkesinambungan (Cultip, Center\& Broom., 2011).

Peran humas antara lain sebagai expert prieciber yaitu bisa menjadi penasehat ahli untuk pimpinan atau perusahaan; humas menjadi problem solving fasilitator diartikan sebagai fasilitator proses pemecahan setiap masalah yang muncul diperusahan ; communication technisian artinya humas mempu menjadi teknisi komunikasi dan bisa meberikan solusi setiap persalahan yang terjadi ; communication fasilitator artinya humas sebagai fasilitator komunikasi atau yang menjembatani perusahan dengan mitra, masyarakat, media, dalam menyelesaikan konflik yang terjadi. Jika dikaitkan dengan fungsi komunikasi korporat humas mampu menjadi fasilitor komunikasi yang handal dalam segala bidang (Ruslan, 2014). Humas juga memiliki beberapa fungsi diantaranya menjalin hubungan harmonisasi antara organisasi dengan publiknya; mampu mengidentifikasi setiap adanya opini, persepsi, bahkan adanya tanggapan masyarakat terhadap organisasi; menjunjung aktivitas manajemen perusahaan dalam mencapai tujuan organisasi; mampu menciptakan suasana komunikasi dua arah antara perusahaan dengan mitra, mampu mengatur informasi yang up date, pesan dari organisasi; sertapublikasi. selainitumemberikan pelayanan kepada publik dan memberikan saran 
yang bijaksana kepada pimpinan, stakeholder perusahan sehingga kepentingan tujuan bersama tercapai. intinya adalah humas sangat berfungsi dalam suatu perusahaan karena bisa menjadi penyelamat, penasehat dan kapanpun perusahan membutuhkan, Humas selalu ada untuk perusahan dan publik (Ruslan, 2014).

Komunikasi korporat merupakan bagian dari fungsi manajemen yang memberikan penawaran kerangka kerja untuk koordinasi afektif semua komunikasi internal dan eksternal dengan tujuan keseluruhan membangun dan mempertahankan reputasi yang menguntungkan dengan kelompok pemangku kepentingan pada organaisasi (Cornelissen, 2004). Lain halnya dengan argenti bahwa fungsi komunikasi korporat humas terdiri dari: identitas, citra, reputasi; CSR; hubungan investor; komunikasi pemasaran; hubungan pemerintah; hubungan media; sistem komunikasi internal;komunikasi krisis (Argenti, 2010).

Fungsi komunikasi korporat humas pertama, defenisi identitas perusahaan adalah merupakan wujud kebenaran yang tercermin karena adanya realita perusahaan seperti yang dipajang kepublik melalui nama perusahaan PTPN V,logo perusahan, motto, visi dan misi,ada produk, layanan perusahaan, bangunan/gedung, alat-alat tulis kantor, seragam karyawan, dengan kata lain identitas merupakan jati diri dari perusahaan. Citra merupakan sebuah kesan yang timbul katena adanya cerminan perusahaan di mata para publik. Sementara itu terkait dari reputasi merupakan hasil dari bagaimana seluruh publik/ konstituen melihat organisasi tersebut (Argenti, 2010).

Fungsi komunikasi korporat humas kedua, yaitu Corporate Social Responsbility (CSR), dapat memberikan kesempatan untuk melayani kepentingan publik karena merupakan sebuah perkembangan positif dimana perusahan benar benar terlibat dalam komunikasi dengan para pemangku kepentingan ,mendengarkan dan mengubah tindakan.merupakan suatu konsep bahwa organisasi,dengan adanya CSR reputasi perusahan meningkat, nilai pemegang saham bertambah, dan para karyawan termotivasi dan bahagia. Sementara itu terkait dengan fungsi komunikasi korporat ketiga, terdapat hubungan dengan media yang merupakan sebuah konstituen sekaligus saluran yang memberikan karyawan, investor, dan tersedianya para konsumen informasi mengenai dan membentuk citra dari sebuah perusahaan (Argenti, 2010). Fungsi keempat, yaitu komunikasi pemasaran terkait hal ini humas bekerjasama dengan departemen komunikasi pemasaran untuk coordinator, mengatur penjadwalan publisitas yang berkaitan terhadap produk baru ,produk lama, harga dan meningkatkan aktivitas yang berhubungan langsung konsumen, iklan korporat. Kelima, terkait dengan komunikasi 
internal sistem perusahan yang meliputi adanya berbagi macam kelengkapan sarana dan prasarana yang disediakan kepada dalam mencapai tujuan tujuan strategis perusahaan.

Fungsi keenam, terkait komunikasi korporat humas dibidang hubungan investor, dimana hubungan investor mampu mewujudkan kerja sama dengan baik,menjaga komunikasi dengan calon para investor/investor dengan komitmen menguntungkan kedua belah pihak baik dinternal atau eksternal public.Sementara fungsi komunikasi korporat ketujuh, terkait hubungan pemerintah terkadang adanya kebijakan dan perubahan kebijakan memberikan dampak positif atau dampak negative bagi perusahaan. Selain itu, melakukan monitoring terhadap pergeseran-pergeseran yang terjadi dalam ideologi dan agenda pemerintah. Fungsi komunikasi korporat kedelapan, yaitu komunikasi krisis. Seiring dengan kemajuan teknologi dan media ketika terjadi krisis korporat dapat diliput secara cepat dalam hitungan persekian detik oleh seluruh media nasional ataupun media internasional, web/ internet, yang dimana dapat didokumentasikan. Karena dewasa ini semakin canggihnya lingkungan media, juga dapat menjadi tekanan yang terbaru dalam berbisnis demi terciptanya kebutuhan akan respon yang semakin canggih terhadap krisis (Argenti, 2010).

Tujuan komunikasi korporat yang dikelola oleh perusahaan melalui humas secara strategis bagi para stakeholder-nya yaitu menyampaikan informasi mengenai perusahan baik secara internal atau eksternal membujuk khalayak yang dituju. Komunikasi yang ditargetkan adalah untuk memperoleh reaksi dari kahlayak berupa dukungan, kolaborasi/ kerjasama dengan khalayak. Sinergi ini sangat penting dan memberdayakan teknologi informasi dengan komunitas yang dituju perusahan melalui media sosial dan media teknologi informasi lainnya (Ganiem \& Kurnia, 2019).

Adapun penelitian ini bertujuan untuk mengetahui fungsi komunikasi, hambatan, dan solusi komunikasi korporat oleh Humas PTPN V Pekanbaru dalam mengatasi isu manajemen dan krisis manajemen PTPN V secara internal dan eksternal publik.

\section{METODE PENELITIAN}

Dalam penelitian kualitatif peneliti itu berperan sebagai perencana, menjadi pelaksana, serta pengumpul data, analisis, bisa menafsir data, dan menjadi pelapor /laporan akhir dari hasil penelitiannya (Sugiyono, 2015). Terkait Pendekatan kualitatif diartikan sebagai suatu pendekatan penelitian yang dilakukan untuk mendeskripsikan fenomena sebagai objek kajian sehingga mencapai tujuan secara deskriptif berbasis subjektivitas. Hal ini disebabkan tidak dapat dibayangkan kenyataan yang terdapat 
dilapangan selanjutnya tidak dapat diprediksi perubahan yang terjadi, serta bermacam sistem nilai terkait berhubungan dengan cara yang tidak dapat diramalkan (Prastowo, 2016).

Pengumpulan data dilakukan melalui teknik wawancara, observasi, dokumentasi,dengan cara ini maka peneliti mampu memperoleh data secara valid dan dapat dipertanggjawabkan secara ilmiah (J.Moelong, 2016). Teknik pengumpulan data dari metode kualitatif dilakukan melalui triangulasi, analisis data bersifat induktif, serta lebih menekankan makna dari pada generalisasi. Namun penelitian deskriftif lebih fokus pada masalah-masalah yang benar-benar terjadi dan data yang diperoleh bisa bersumber dari naskah dan dokumen resmi lainnya (Miles, M.B, Huberman, A.M, dan Saldana, 2014).

Selanjutnya teknik pengumpulan data merupakan adalah langkah awal peneliti paling strategi sebab tujuan utamanya antara lain untuk mendapatkan data penelitian yang akurat, sehingga jika peneliti tidak dapat mengetahui teknik pengumpulan data maka tidak mendapatkan data yang memenuhi standar yang ditetapkan (Sugiyono, 2015). Selanjutnya Teknik pengumpulan data ini antara lain wawancara diartikan sebagai percakapan yang dilakukan oleh dua pihak yaitu pewawancara (interviewer) yang mengajukan pertanyaan dan yang diwawancari (interviewee) yang memberikan jawaban atas pertanyaan yang telah diberikan (J.Moelong, 2016). Peneliti juga menggunakan metode wawancara semi terstruktur dalam pelaksanaanya lebih bebas (Sugiyono, 2015).

Wawancara semi terstruktur bertujuan untuk menemukan permasalahan secara lebih terbuka, dimana humas,karyawan yang diwawancarai diminta pendapat ideide; observasi, penelitian ini pelaksanaannya tidak terlihat langsung dengan aktivitas orang yang diamati hanya sebagai pengamat yang tidak terikat. Pada teknik observasi, peneliti melakuan pengamatan di PTPN V kemudian peneliti dokumentasikan. Studi dokumen merupakan pelengkap dari penggunaa metode observasi dan wawancara (Sugiyono, 2015). Untuk menguji keabsahan data maka dilakukan dengan triangulasi yaitu teknik mengabungkan teknik pengumpulan data yang berbeda-beda untuk mendapatkan sumber data yang sama.

Teknis analisis yang peneliti gunakan antara lain meliputi: data reductions, artinya peneliti mengumpulkan data yang berkaitan dengan masalah penelitian; data display, artinya peninjauan data bisa dilakukan dalam bentuk uraian singkat, sejenisnya artinya teks yang bersifat naratif; verification data, artinya peneliti melakukan penarikan kesimpulan data dengan menemukan makna baru terkait penelitian yang dilaksanakan (Sugiyono, 2015). 
Jenis dan sumber data penelitian ini antara lain mengunakan dua sumber antara lain: data primer adalah data langsung yang diperoleh melalui sumber data pertama di lapangan berupa tanggapan,respon dari pertanyaan yang disampaikan oleh peneliti. Dalam penelitian ini yang peneliti dijadikan sebagai data primer adalah hasil observasi peneliti yang ditemukan dilapangan yaitu pada PT. Perkebunan Nusantara V Pekanbaru, dan kedua sumber data dipaparkan dari hasil wawancara informan Kabag. Humas PTPN V Staf Humas, dan Karyawan 2 Orang. Penelitian ini berlangsung di PTPN V J1. Rambutan No.43 Pekanbaru.

Data sekunder adalah data yang diperoleh dari sumber kedua. Terkait dalam hal ini artinya data ini dapat diperoleh dari perusahaan atau instansi yang telah tersedia baik berbentuk catatan atau dokumentasi. data primer pada penelitian terdahulu selanjutnya telah diolah lebih lanjut bersumber dari dokumen, bukubuku,arsip penting,serta dokumen instansi/ perusahaan selain itu peneliti memperoleh data sekunder dalam penelitian melalui pengarsipan data seperti profil perusahaan,press realese, dokumen-dokumen seperti foto maupun salinan yang diterima peneliti dari humas PTPN V untuk kelengakapan data utama.

\section{HASIL DAN PEMBAHASAN}

Hasil penelitian yang peneliti peroleh dilapangan dengan cara observasi, wawancara dengan informan dan data-data dokumentasi maka didalam penelitian membuktikan bahwa berdasarkan terhitungnya sejak 14 Februari 1996 PTPN V dikeluarkannya PP (Peraturan Pemerintah) Republik Indonesi No. 10 tahun1996 awalnya merupakan Badan Usaha Milik Negara PT Perkebunan (PTP) II, PTP IV dan PTP V di Provinsi Riau.menjelaskan bahwasanya penyetoran modal negara Republik Indonesia untuk pendirian perusahaan.

Berdasarkan hasil penelitian terdapat delapan fungsi komunikasi korporat humas pada PTPN V dari kedelapan fungsi komunikasi korporat memang sudah sesuai fungsi manajemen perusahan akan tetapi ada empat fungsi komunikasi korporat yang mengalami masalah dan permasalahan tersebut sudah diselesaikan oleh humas melalui komunikasi korporat. Peneliti akan menguraikan hasil sesuai rumusan masalah penelitian yaitu mengetahui apa sajakah permasalahan dibidang fungsi komunikasi korporat yang dihadapi oleh humas PTPN V. Untuk mengetahui apa sajakah hambatan dan solusi apa sajakah yang digunakan oleh humas dalam mengatasi isu manajemen dan krisis manajemen PTPN V secara internal dan eksternal publik. Fungsi komunikasi korporat yang dihadapi oleh humas PTPN V terdiri dari:

Pertama, Identitas, Citra dan Reputasi. 
Identitas PTPN V ada 3 bagian yaitu logo, seragam, warna perusahaan disebut juga dengan istilah coporate design, selanjutnya corporate communications berupa iklan, public relations, dan adanya informasi, kemudian corporate behavior diartikan adanya nilai-nilai internal, normadiPTPNV.Selanjutnyaterkait citraadalah seperangkat nilai atau anggapan serta impresi dari gambaran seseorang atau sekelompok orang mengenai suatu objek bersangkutan Nova (2011). Citra PTPN V tergambar dari cara Humas PTPN V dalam mempublikasikan pesan dilakukan secara tepat sasaran sehingga mampu mengumpulkan awareness dari public dan menumbuh kembangkan citra positif publik kepada perusahaan. Berdasarkan hasil wawancara dengan Kasubag Humas PTPN V Subhan Fitrial;

"Kita semua baik internal dan eksternal berusaha untuk tetap menjaga identitas, citra dan reputasi PTPN V .untuk mewujudkan itu perlu reputasi yang baik pula dari perusahaan. Terkait permasalahan yang ada dimedia kita sudah menyelesaikan masalah dengan petani plasma untuk tetap bermitra karena kita ingin menjalin hubungan baik dengan mitra janganlah sampai reputasi perusahaan buruk dimata warga".

Selanjutnya wawancara dengan informan karyawan PTPN V ibu Shinta, yang menjelaskan bahwa:

"Saya sebagai karyawan menilai bahwa humas senantiasa menjaga komunikasi korporat melalalui identiatas, citra dan reputasi perusahan, meski ada car pemberitaan negatif yang datang dari internal dan eksternal tapi humas dengan cepat mengatasi masalah, menjaga perusahaan dengan mencapai target, bisa beroperasi excellent di indonesia. Saya harap perusahaan terus berinovasi".

Untuk reputasi PTPN V tetap meraih reputasi peringkat pertama KPKU (pengukuran kriteria kinerja unggul) dengan nilai $(501,75)$. Selanjutnya penghargaan langsung diberikan bapak direktur operasi dan pengembangan PTPN III (persero) yaitu bapak Mahmudi dan penyerahan langsung diterima bapak direktur utama PTPN V Pekanbaru, Jatmiko K. Santosa, di hotel Hilton Bandung.

Data pada gambar 1, menunjukan bahwa adanya peningkatan reputasi perusahaan yang diterima poleh PTPN V. Reputasi korporat ini adalah modal sosial bagi PTPN V, reputasi merupakan aset tidak kasat mata, bagi

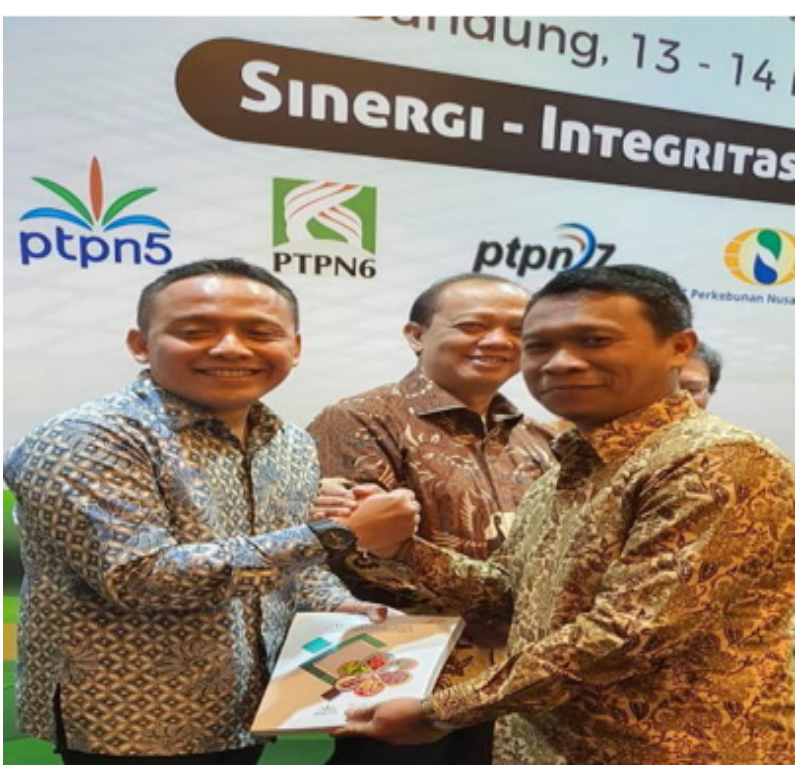

Sumber: Humas PTPN V, 2020

Gambar 1 Pemberian Penghargaan kepada PTPN V 
perusahaan, reputasi bisa dilihat, bernilai nyata yaitu dapat dihitung secara ekonomi, karena reputasi harus dikelola dengan kesungguhan dimonitor, diukur, dikembangkan dengan rencana matang (Doorley \& Garcia, 2011). Reputasi yang buruk atau tidak memiliki reputasi juga memiliki sedikit peluang untuk berkembang menghadapi hambatan dalam menjalankan fungsi bertujuan komunikasi korporat. Humas dalam aktivitasnya tentu saja bekerja untuk memperbaiki citra dan reputasi perusahaan saat konflik terjadi dan mengidentifikasi masalah sehingga citra dan reputasi di PTPN V tetap stabil.

Tujuan humas meliputi citra positif (good image), saling pengertian (mutual understanding), toleransi dengan publik, good will itu diartikan adanya kemauan baik humas pada public, mutual appreciation artinya saling menghargai (Ruslan, 2014). Dalam ruang lingkup internal, humas berupaya menanamkan sense of belonging yaitu rasa memiliki terhadap perusahaan dan sense of responcibility yaitu rasa taggung jawab yang diberikan kepada seluruh karyawan, manajemen, para pekerja juga kepada pemegang saham dan lai -lain. Humas juga bertanggung jawab menciptakan citra dan reputasi pada publik eskternal yaitu masyarakat(community), mewujudkan hubungan yang sehat serta saling menguntungkan antara pemerintah kepada perusahaan, media/ pers, customer, Citra itu sebagai gambaran dari mental perusahaan sedangkan makna reputasi adalah rekam jejak (Ardianto, 2013).

Fungsi kedua, yaitu Tanggungjawab Sosial Perusahaan itu sama dengan Corporate Social Responcibilty (CSR). CSR didefinisikan sebagai terciptanya rasa komitmen oleh perusahaan untuk melakukan perubahan dalam meningkatkan kesejahteraan komunitas melalui praktik bisnis yang baik dan meberikan kontribuksi dari berbagai sumber daya (Gasing \& Suryanto, 2016). PTPN V memiliki tanggung jawab terhadap karyawan, pemegang saham, komunitas, dan lingkungan pada semua aspek operasional perusahan dalm hubungan yang aktif dan berarti seperti pada masalah yang berdampak limbah polusi keamanan, produk dan tenaga kerja. Hasil wawancara peneliti dengan Humas PTPN, Bapak Risky Atriyansyah terkait komunikasi humas dalam Program CSR: "CSR sudah diberikan pada peternak 60 orang peternak lele dan anak sapi. Sebesar 2,5 miliar. Diberikan secara langsung oleh Direktur Utama PTPN V Jatmiko K. Santoso. dan saksikan Bupati Sugeng Susanto bertempat di aula rumah dinas Bupati Kampar”.

Selain CSR PTPN V juga sedang melaksanakan Program Pembinaan Usaha Kecil (PPUK) yaitu program kemitraan perusahaan dengan menggunakan dana dari alokasi hasil laba/keungtungan perusahaan.Analisa peneliti 
dalam komunikasi korporat humas sudah efektif dan efesien karena setiap kegiatan ada transparan pada media dan publik. Selanjutnya CSR dikatakan berhasil karena tidak pernah bisa lepas dari peran humas, ada juga peran masyarakat, para pengusaha, serta pemerintah. Namun CSR tidak pula hanya pada pemberian bantuan dana kepada lingkungan sosial, tetapi bagaimana perusahaan menjaga hubungan baik karyawan, dengan pemasok,tidak ada diskriminatif. Secara singkat corporate social responcibility adalah bagaimana memperlakukan semua pemangku kepentingan (stakeholders) secara bertanggung jawab dan etis (Sagala \& Chairuna, 2015).

Fungsi ketiga, adalah berhubungan dengan media. Antara humas dengan media massa harus saling memanfaatkan dan saling menguntungkan dalam penanganan kriris diperusahaan. Berikut adalah hasil wawancara yang peneliti dapat dari bagian staf Humas PTPN V terkait hubungan media:

"Menjaga hubungan baik dengan media secara terus menerus perlu karena untuk keberlangsungan perusahaan yang sehat dan untuk menyampaikan fungsi komunikasi korporat yang ada di PTPN V" Media berperan penting untuk mendongkrak citra dan reputasi yang positif sehingga publik internal/esternaldapat meberikan penilaian. meskipun kadang awal muncul fenomena negative berawal dari media,tapi kita menjaga komunikasi pada media untuk mengklarifikasi dengan data yang dapat diakui kebenarannya".

Peneliti menilai dalam wawancara diatas bahwa humas PTPN V berperan aktif dalam menjalin hubungan dengan media akan tetap membutuhkan media sebagai sarana dalam mempublikasikan, mengklarifikasi setiap masalah yang muncul dan diberitakan terkait isu negatif atau positif dan jumpa pers di PTPN V menciptakan hubungan antara perusahan dengan media dibangun atas dasar kepercayaan, yaitu tanggung jawab sosial, keakuratan informasi, kenyamanan (Ganiem \& Kurnia, 2019). Dalam membina hubungan media korporat sebaiknya memilih saluran yang tepat. Media massa ada juga yang melakukan rekayasa untuk mempengaruhi dan menguasai masyarakat.

Fungsi keempat, adalah komunikasi pemasaran. Menurut Kusniaji, komunikasi pemasaran didefenisikan sebagai bentuk komunikasi yang bertujuan dalam memperkuat strategi pemasaran dan aplikasi komunikasi yang bertujuan untuk membentuk kegiatan pemasaran yang terdapat di perusahaan (Kusniadji, 2016). Selanjutnya komunikasi pemasaran merupakan kegiatan yang ditujukan untuk menjalin, memperkenalkan, menciptakan interaksi antara perusahaan dengan mitra atau pada konsumen. Disebut juga salah satu usaha dalam mengkomunikasikan perusahaan produk, jasa pada pihak luar baik mitra suplier atau konsumen. Berdasarkan wawancara peneliti dengan bapak Risky Atriansyah, menjelaskan: 
"Fungsi Humas dalam komunikasi pemasaran menjadi salah satu bagian yang sangat penting di PTPN V terutama bagi penggerak sebuah perusahaan kan kita ingin mencapai target ISCC $100 \%$ jadi harus ada strategi komunikasi pemasaran yang baik harus dilakukan secara hati-hati dan penuh perhitungan dalam menyusun rencana, mempresentasikan pesan pada publik selaku konsumen mengenai produk atau jasa yang akan dipasarkan oleh PTPN V'.

Fungsi Humas dalam komunikasi pemasaran di PTPN V yaitu membentuk merek, kemudian dalam pemilihan media juga harus tepat karena dapat dijadikan sarana penyambung perusahaan dengan konsumen, meyakinkan konsumen, mengelola pemasaran dengan baik, alat ukur keberhasilan pemasaran, merancang menentukan target, alat meningkatkan penjualan, mempelajari pasar, memutuskan strategi promosi yang tepat, sales promotion, membentuk citra perusahaan, referensi pembanding.

Data pada gambar 2, menunjukan terjadinya kegiatan komunikasi pemasaran di PTPN V. Selanjutnya fungsi kelima, adalah komunikasi internal. di PTPN V berperan penting dalam proses penyebaran informasi dalam perusahaan.

Penerimaan komunikasi internal yang baik akan berdampak pandangan yang sama untuk menjalankan visi dan misi sebagai tujuan untuk keberlangsungan organisasi/ perusahaan bersama. komunikasi akan berhasil efektif apabila timbul rasa saling pengertian.

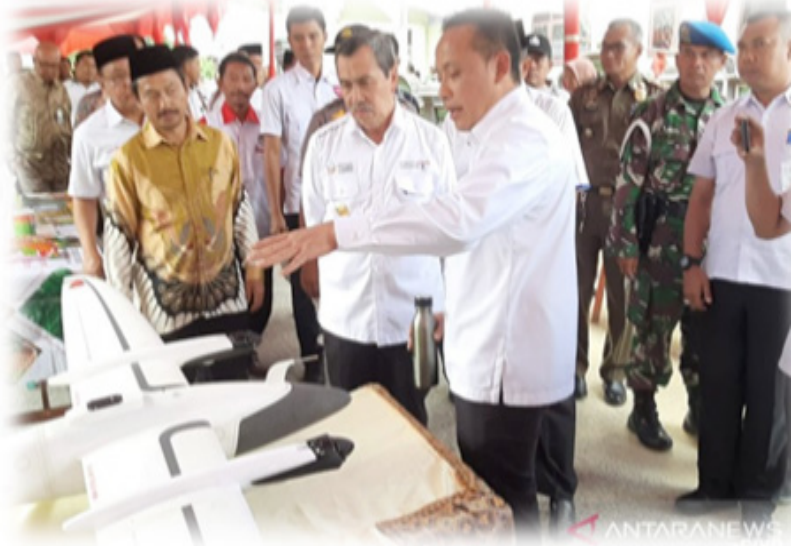

Sumber: Humas PTPN V, 2019

Gambar 2 Komunikasi Pemasaran PTPN V

Berdasarkan hasil wawancara peneliti dengan informan bapak Risky Atriyansyah, menyebutkan:

"iya di internal perusahaan komunikasi kita terkadang kendalanya pada karyawan karyawan demo menuntut kesejateraan karywan dan bnyak lagi sperti system internal komunikasi IT yang kita gunakan tapi itu kita harus bijak dalam menyelesaikan masalah yang ada demi kebaikan bersama untuk itu hubugan antara perusahaan dan karyawan dituangkan dalam perjanjian kerja bersama".

Berdasarkan hasil observasi peneliti di PTPN V bahwa di sistem internal komunikasi perusahaan menerapkan teknologi wide area network; Very Small Apperture Terminal; Fiber optic dan wave lan selanjutnta untuk sistem komunikasi data infomasi yang digunakan antar kebun/ unit melalui sarana via telepon, teknologi, berita,laporan,dan pengiriman data lainnya. Selanjutnya peneliti melihat terdapat pemasangan CCTV di 12 pabrik 
perusahaan kebun. Sehingga dapat memonitor segala aktivitas disetiap pabrik cukup dari kantor pusat jika ada kendala baik internal atau eksternal publik. Pengembangan sistem komunikasi internal PTPN V telah memiliki banyak aplikasi mulai dari tahun 2012 sampai sekarang seperti; online aplikasi RKAP; online pengolahan; online aplikasi tanaman; aplikasi SIPT; e-procurment aplikasi; Pengembangan web internet dan email menjadi sistem office; business inteligence aplikasi, apalikasi layanan TI; berdasarkan hasil identifikasi pengembangan rencana stategis sistem infomasi dan teknologi informasi dilaksanakan dalam rangka meningkatkan keselarasan dengan jangka waktu 5 tahun. Tentunya pengembangan dan investasi SI/TI yang dilakukan perusahaan dapat terarah dengan baik serta memberikan manfaat sesuai harapan, sehingga tidak ada kesenjangan yang mengurangi resiko terjadinya kegagalan. Kemudian Departemen Corporate Communication melakukan filtrasi sendiri atas informasi yang didistribusikan bagaimana sebuah pesan bisa diterima dengan baik. Selanjutnya peran sosialisasi yang dilakukan oleh departemen Corcom cukup penting karena hampir semua kegiatan komunikasi internal yang terjalin dan terjadi di antara perusahaan dengan karyawan melalui media internal (Bangun, 2016).

Fungsi keenam, Terkait hubungan investor. adalah kegiatan pemasaran korporat humas yang berupaya memberikan gambaran tepat mengenai kinerja perusahaan, prospek perusahaan kepada investor dan calon investor. Dengan tujuan memberikan dampak yang positif tehadap PTPN V. Wawancara peneliti dengan bapak Risky Atriyansyah terkait komunikasi humas:

" kami senantiasa menjalin komunikasi dengan para investor .tujuannya untuk kerja sama untuk mewujudkan itu tetap dijalur fungsi manajemen humas,dan saat ini perusahaan berhasil mendapat investor dari BRIN".

Selaras dengan hasil penelitian yang peneliti uraikan menyatakan bahwa investor adalah salah satu pilar organisasi yang berperan sebagai energi dalam mengembangkan perusahaan kearah yang lebih maju (Yanuar, 2017). Penelitian ini juga menunjukkan bahwa dengan demikian hubungan investor bisa mengurangi biaya modal perusahaan (lower capital costs), menarik investasi baru (attract new invesment).

Data pada gambar 3, menunjukan adanya kegiatan hubungan investor investor dari BRIN dengan PTPN V. Humas perlu menyongsong kredibilitas tinggi dimana karyawan dapat diandalkan, dan masyarakat memerlukan perusahaan yang bertanggung jawab. Fungsi hubungan investor antara lain; menjadi penghubung antara perusahaan dan investor; memahami dan responsip terhadap kebutuhan 


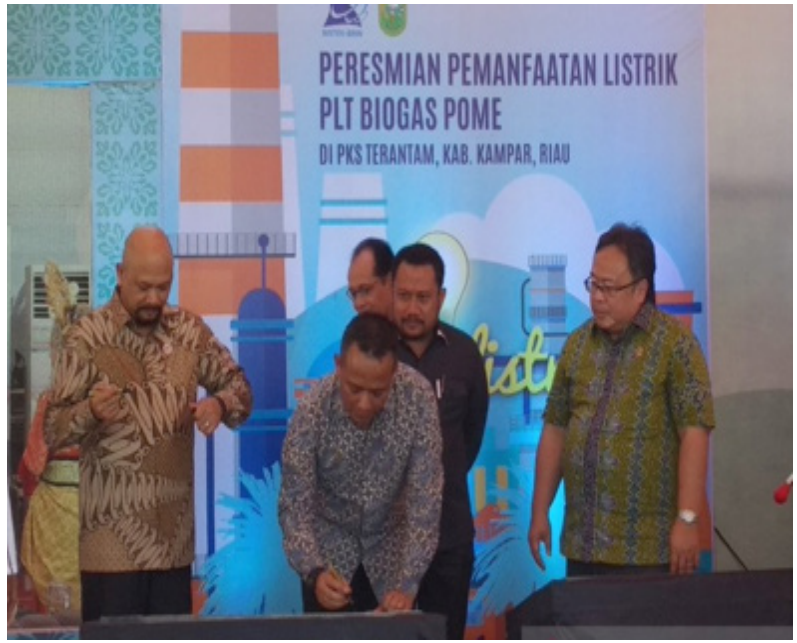

Sumber: Humas PTPN V, 2020

\section{Gambar 3 Kegiataan hubungan investor PTPN V dengan BRIN}

investor dan perusahaan; menarik, merawat, dan mempertahankan investor. Berdasarkan hasil wawancara yang diperoleh peneliti menyimpulkan bahwa hubungan investor penting untuk dipertahankan, dirawat, dipelihara rasa kepercayaan, tanggung jawab kinerja dan menghindari kegagalan target perusahaan.

Fungsi ketujuh, adalah Goverment Relations terkait dengan hubungan pemerintah merupakan suatu bagian khusus dari tugas dari seorang humas yang membangun dan memelihara hubungan dengan pemerintah terutama untuk kepentingan yang dapat memberikan pengaruh terhadap peraturan dan perundang-undangan (Kuncoro, 2015). Selanjutnya hubungan pemerintah melakukan kegiatan komunikasi bertujuan untuk lobi dan negoisasi dengan pemerintah. dalam jurnal ini dipaparkan bahwa lobi terdapat tiga bentuk strategi goverment relations, yaitu; dan political Action Commitees (PACs), Grassroott Lobbying lobi langung (Kuncoro, 2015).

PTPN V dan Humas senantiasa menjaga hubungan baik dengan pemerintah diharapkan terjalin kinerja sinergis pelayanan negara terhadap rakyat dapat diwujudkan. Terkait hal lainnya harus memahami kebijakan dan regulasi pemerintah, menginterpretasi kebijakan dalam hubungannya dengan perusahaan. Sumber informasi yang peneliti peroleh dari humas PTPN V terkait pengembalian lahan 2.800 Ha.

Lahan itu sebenarnya sudah sesuai prosedur berdasarkan ijin pengelolaan dari negara serta PTPN V telah konsisten mengikuti arahan pemerintah sebagai pemegang saham.Menurut Jatmiko:

"Tentunya ketika pemerintah menugaskan kami mengembalikan lahan tersebut, maka kami kembalikan ke negara. Setelah dikembalikan ke warga oleh pemerintah, untuk selanjutnya pengelolaan lahan $2.800 \mathrm{Ha}$ dan aset yang berada diatasnya, akan dilaksanakan melalui kerjasama pola kemitraan antara warga dengan PTPN V".

Selanjutnya peneliti menyimpulkan bahwa PTPN V telah menyelesaikan permasalahan dengan pemerintah terkait penggugatan eksekusi lahan oleh LSM Riau Madani. Secara resmi mengembalikan lahan seluas 2.800 hektar kepada negara lahan tersebut akan diserahkan kepada warga Desa Senama Nenek, Kabupaten Kampar, Riau. Pengembalian 
lahan ini melibatkan pemerintah, media, pers, humas, warga diharapkan dapat meningkatkan kemitraan positif perseroan dengan warga Desa Semana Nenek keuntungan bagi negara dan kemaslahatan kepada stakeholder, dalam penyelesaikan masalah ini tidaklah mudah karena ada proses panjang dalam menyampaikan informasi yang penting terkait perkembangan perusahaan; isu yang berhubungan dengan kepentingan perusahaan pemerintah; membuat laporan keuangan; CSR; membantu pemerintah atau regulator memiliki pemahaman yang tepat tentang perusahaan demi menghindari kesalahpahaman. Selain itu, hasil wawancara peneliti dengan informan terkait dengan hubungan pemerintah humas PTPN V memberikan pernyataan:

"PTPN V melakukan penandatanganan nota kesepahaman dengan Asosiasi Petani Kelapa Sawit Indonesia (Apkasindo). Nota kesepahaman tersebut merupakan tindaklanjut dalam pelaksanaan program sawit untuk rakyat yang dicanangkan pemerintah kita tertib mengikuti program pemerintah"

Melalui kerja sama program BUMN Untuk sawit rakyat tersebut diharapkan terjadi peningkatan produktivitas hasil dari kebun kelapa sawit rakyat melalui kerja sama kemitraan, kelembagaan perekebunan, sumber daya manusia, karyawan, dan percepatan pelaksanaan program peremajaan kelapa sawit. PTPN V memang disiapkan untuk bermitra dengan petani diantaranya seperti pemerintah daerah, Himbara, BPDPKS dalam upaya mewujudkan sawit rakyat swadaya secara ekonomi dan terjadinya peningkatan kesejahteraan petani.

Data gambar 4, menunjukan bahwa adanya kerjasama perusahaan dengan pemerintah seperti penandatanganan nota kesepahaman bersama Apkasindo untuk mengikuti program pemerintah. Fungsi kedelapan, adalah komunikasi krisis. Menurut Puspitasari, kehadiran krisis pada perusahaan dapat di ibaratkan seperti layangan saaat diterbangkan diudara akan putus talinya ditiup angin berhembus yang kerap hadir tanpa ada dugaan maupun perkiraan (Puspitasari, 2016). Munculnya krisis sering kali menimbulkan keresahan bagi tiap-tiap pemangku kepentingan, kapan dan dimana bisa datang menghampiri.

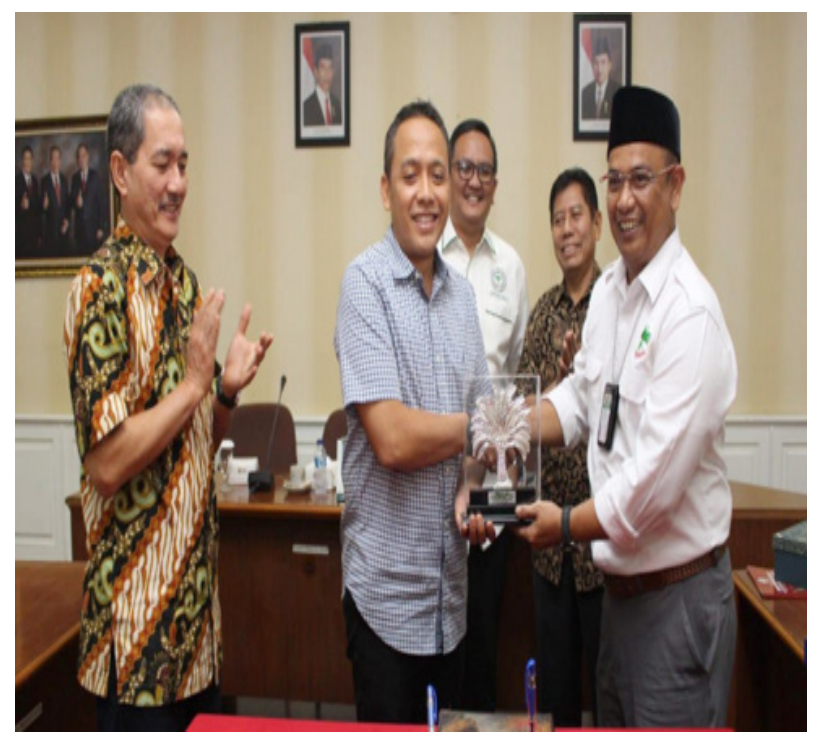

Sumber: Humas PTPN V

Gambar 4 Kerjasama PTPN V- Apkasindo, 2019 
Krisis menjadi sebuah ancaman nyata bagi citra atau reputasi perusahaan.

Strategi dan taktik komunikasi diperuntukkan ketika menghadapi krisis dan memperbaiki citra dan reputasi pasca kriris. dalam manajemen krisis yaitu berorientasi pada keselamatan publik, humas juga menerapkan strategi komunikasi krisis yang dirumuskan dengan: mengurangi resiko muncul kepanikan publik;memberikan perlindungan kepada perusahaan dari ktitikan bahkan spekulasi negatif muncul dimedia massa; mengurangi spekulasi khususnya diawal-awal kriris; accountability, disclusure, symmetricial communication, untuk meminimalisir terjadinya kerusakan pada citra organisasi (Kriyantono, 2012). Komunikasi krisis terkait dengan penggunaan semua peralatan public relations untuk memperkuat reputasi PTPN $\mathrm{V}$ baik internal publik atau eksternal publik. Penyebab krisis ini biasa terjadi pada kesalahan SDM, keputusan manajemen atau masalah mekanis dan lain lain. Berdasarkan wawancara dengan informan karyawan Shinta:

"Ini adalah perusahan besar sudah biasa terjadi demo atau kriris komunikasi kadang banyaknya tuntutan karyawan terhadap perusahaan, yang didemokan adalah tuntutan upah,bonus karyawan dan kesejahteraan karyawan tapi kriris yang terjadi bisa teratasi dengan proses waktu yang tidak singkat".

Sementara itu humas selaku pelaksana dalam kegiatan komunikasi korporat mampu mengekspresikan konsep stragis perusahaan kepada stakeholders dan menjadi sarana untuk untuk mendorong produktivitas karyawan dalam mencapai tujuan. Dalam pelaksanaan fungsi komunikasi korporat oleh humas PTPTN V ditemukan beberapa hambatan. Pertama, hambatan komunikasi korporat yang disebabkan oleh isu manajemen internal dan eksternal. Peneliti mengartikankan bahwa manajemen isu suatu proses kegiatan yang dapat menghentikan munculnya isu kemudian berkembang menjadi krisis. Regester dan Larkin menyebut isu sebagai kesenjangan antara praktik yang dilakukan perusahan dan harapan dari para pemangku kepentingan (Regester \& Larkin, 2005). Masalah yang teridentifikasi dengan cepat dapat dilakukan humas PTPN V dengan mengubah rencana atau mengalihkan upaya komunikasi yang paling sesuai. Wawancara peneliti dengan bapak Risky Atriyansyah; "Yang menjadi hambatan kami di PTPN $\mathrm{V}$ adalah secara internal dan ekternal. jika di internal masih perlu ditingkatkan sistem komunikasi internal karyawan, eksternalnya adalah adanya isu manajemen dan kriris kadang datangnya dari media luar pemberitaan yang tidak baik terkait PTPN V".

Kedua, hambatan yang disebabkan oleh krisis manajamen. PTPN V beruntung karena selama satu dekade terakhir telah berjuang keras perbaiki diri. PTPN V pernah juga kesulitan bayar gaji. Berdasarkan sifatnya krisis dapat terjadi sewaktu waktu dan ketika kriris melanda 
PTPN V langkah yang paling krusial dilakukan adalah: accountability, disclusure, symmetricial communication, yang didesain humas PTPN $\mathrm{V}$ untuk meminimalkan kerusakan pada citra organisasi secepatnya merespon krisis; membuat perencanaan yang cermat dan kunci penting kesuksesan penagangan krisis; humas dalam menanggapi kriris juga harus lebih waspada terhadap media modern yang didukung pada berita bergulir maupun situsblog, jejaring sosial media sehingga tidak membuat situasi semakin buruk.

Krisis komunikasi di perusahaan bisa terjadi kapan saja dengan waktu yang tidak terduga. Saat hal ini terjadi humas sebagai pelaksana fungsi komunikasi korporat harus mengeluarkan semua jurus skill komunikasi terbaiknya untuk mengatasi masalah khususnya yang terjadi di PTPN V. Good corporate governance adalah sebagai perusahaan agribisnis terintergrasi, berwawasan yang sehat, berkelanjutan dibutuhkan pengelolaan perusahaan yang tepat sasaran. Untuk mengatasi isu manajemen dan kriris manajemen pada tanggal 23 Desember 2014 PTPN V menerbitkan pedoman manajemen resiko. Mengembangkan implementasi manajemen risiko dengan tujuan akhir bahwa tidak hanya kewajiban namun manajemen resiko merupakan salah satu kebutuhan yang memudahkan PTPN $\mathrm{V}$ mencapai target jangka pendek atau jangka panjang. Di Tahun 2018 dilakukan revisi pada perubahan struktur organisasi dan terhadap pedoman, standar manajemen resiko ISO 31000:2009 Terkait isi dari perubahan tersebut antara lain adanya penyederhanaan terhadap buku pedoman manajemen resiko terdiri tiga buku dirubah menjadi satu buku.

Pembahasan peneliti humas sebagai pelaksana komunikasi korporat harus bisa memberikan solusi yang terbaik untuk manajemen karena dengan solusi tersebutlah dapat mengendalikan kriris yang terjadi. Mengapa kriris dalam perusahan harus di organisir dengan baik tentu saja karena PTPN V memiliki stakeholders yang langsung merasakan dampak negatif apabila terjadi krisis. Terkait dengan image PTPN V dimata publik, karena dewasa ini adalah era digitalisasi dimana laju arus informasi sangat cepat menyebar luas, mudah dikonsumsi, dinikmati publik. Dengan demiikian humas tentunya harus kompeten dalam mengelola krisis yang tidak dapat diprediksi kapan terjadinya hal tersebut. Selanjutnya ketika krisis menerpa perusahaan seluruh stakeholders menjadi korban dari efek kriris tersebut. Untuk menangani krisis komunikasi korporat terkait hal ini, humas berupaya menyampaikan pesan kepada publik dengan cara memiliki (commitment) untuk untuk menyelesaikan masalah, menemukan sumber terjadinya kririsis; (care) merupakan 
wujud bentuk perhatian yang mendalam pada perusahaan menunjukkan rasa peduli dan empati yang sungguh-sungguh dari pihak perusahaan terhadap stakeholder yang terkena dampak krisis; (clarity) yaitu perusahaan selaku PTPN V memberikan pesan yang jelas mudah dipahami sederhana dan tidak ambigu agar tidak berkembang informasi yang salah, accountability, disclusure, symmetricial communication karena di zaman era digital siapapaun bisa mengolah kembali informasi yang sebenarmya menjadi berita hoax yang malah memperkeruh suasana kriris dalam perusahaan; consistency andcoherency, wujud dari rasa konsistensi perhatian tanggung jawab atas krisis yang melanda. Hal-hal yang telah dilakukan PTPN V sebagai solusi untuk mengatasi berbagai hambatan komunikasi korporatnya antara lain: lingkungan ekologis, karyawan, petani plasma, bina lingkungan dan pengolahan limbah.

Berdasarkan penuturan Humas PTPN V solusi komunikasi korporat yaitu:

"Melalui lingkungan ekologi karena isu miring kerusakan lingkungan hidup akibat alih fungsi hutan menjadi areal perkebunan merupakan salah satu kampanye negatif karena secara tidak langsung dapat memengaruhi citra dan kinerja perusahan, dengan penerapan ISO 14001:2004 dan kerjasama dengan BAPEDAL Propinsi dan Kabupaten"

Humas melakukan pengawasan di seluruh kegiatan operasional pabrik ataupun kebun yang dikelola perusahaan bertujuan tidak menganggu serta merusak kelestarian lingkungan hidup antara lain melalui : adanya pemantauan lingkungan secara rutin diseluruh pabrik; adanya pemantauan kinerja IPAL (Instalasi Pengolahan Air Limbah); adanya kajian awal; perancangan dan pengembangan sistem manajeman lingkungan. Adanya pemberian fasilitas memadai dari PTPN V pada karyawan, seperti fasilitas kesehatan, peribadatan, ekonomi, olahraga dan lainnya.

Selanjutnya untuk peningkatan dilakukan pembinaan karyawan pelaksanaannya sangat terstruktur seperti adanya pemberian kepada karyawan punishment dan reward, mutasi karyawan dan promosi jabatan Sementara itu, pengembangan karyawan dapat dilakukan melalui pendidikan lanjutan,program pelatihan, seminar, bimbingan teknikyang diselenggarakan secara internal di PTPN V, menyediakan peluang berkarir sesuai kelayakan dan kemampuan karyawan dan uji kelayakan sesuai standar perusahaan. Perusahaan juga memberikan manajemen pembinaan,memberikan bantuan kepada masyarakat petani plasma, sehingga keberadaan PTPN V sebagai perusahaan yang berandil besar menjadi faktor untuk meraih kesuksuksesan karena telah memberikan standar kehidupan baik bagi para petani.

Solusi selanjutnya dalam upaya mengatasi hambatan fungsi komunikasi korporat oleh 
humas dilakukan melalui bina bingkungan berupa bantuan bencana alam, insfrastruktur, bina sektor pendidikan, bina sektor kesehatan dan bina sektor kerohanian. PTPN V juga selalu berupaya untuk tidak mencemari lingkungan masyarakat untuk mewujudkan kondisi yang sehat, nyaman aman PTPN V menganalisa (zero burning land aplication) pencemaran limbah melalui pengolahan limbah sehingga tanah, udara dan air bersih tetap terjaga dengan teknologi yang ramah lingkungan.

"Direktur Utama PTPN V Jatmiko K Santosa menyampaikan bahwa perusahaan perkebunan plat merah itu terus berusaha menerapkan konsep sawit lestari, termasuk dalam pengelolaan limbah sawit baik cair maupun padat. Ia mengatakan saat ini produktivitas PTPN V telah melampaui perkebunan sawit milik negara di daerah lainnya, bahkan perusahaan sawit swasta sekalipun. Namun, dia mengatakan memiliki masalah klasik yakni biaya produksi yang tinggi, sehingga dengan memanfaatkan limbah sebagai sumber energi listrik dapat menjadi solusi yang akan terus dikembangkan di masa mendatang".

Solusi terakhir dalam mengatasi hambatan fungsi komunikasi korporat adalah mewujudkan pelaksanaan pembangunan proyek siak kebun kelapa sawit kepada masyarakat dengan luas proyek lebih kurang terdiri dari 3.500 Hektar di Kecamatan Sungai Apit dan tahap ke dua luasnya adalah $5.182 \mathrm{Ha}$.

\section{SIMPULAN}

Pertama, hasil penelitian menunjukkan bahwa fungsi komunikasi korporat oleh humas PTPN V sudah terlaksana sesuai dengan fungsi manajemen dalam perusahaan melalui upaya membangun dan mempertahankan identitas, citra dan reputasi, CSR, hubungan media, krisis komunikasi, hubungan dengan pemerintah, hubungan dengan para investor, pada komunikasi pemasaran, dan sistem komunikasi internal.

Kedua, kegiatan fungsi komunikasi korporat Humas PTPN V berpedoman pada empat fungsi komunikasi korporat yang mengalami masalah dan telah diselesaikan secara baik di sektor internal dan eksternal publik.

Ketiga, hambatan komunikasi korporat yang dihadapi oleh humas di PTPNV terjadi pada isu manajemen dan krisis manajemen yang mampu diatasi dengan cara melaksanakan: accountability; disclusure; symmetricia communication; consistency andcoherency; commitment; clarity; and care.

Keempat, solusi komunikasi korporat yang dilakukan oleh humas PTPN V dalam mengatasi hambatan perusahaan dalam memecahkan masalah isu manajemen dilakukan dengan cara lebih mengutamakan kesejahteraan karyawan dan memberikan solusi tepat sasaran dan transparan kepada publik; menguntungkan masyarakat luas; melakukan pembinaan lingkungan ekologis; membina karyawan; 
melakukan pengolahan limbah; solusi petani plasma.

Berdasarkan kesimpulan diatas maka peneliti menyarankan bagi perusahaan PTPN $\mathrm{V}$ dalam setiap mengatasi isu dan krisis manajemen sebaiknya mampu bekerja sama dengan media relation agar tidak lebih sering muncul pemberitaan negatif pada perusahaan yang dapat merusak citra atau reputasi di PTPN V Pekanbaru.

\section{DAFTAR PUSTAKA}

Ardianto, E. (2013). Hanbook of public relations: pengatar komprehensif. Bandung: Simbiosa Rekatama Media.

Argenti, P. (2010). Komunikasi korporat ( putri aila idris (ed.); terjemahan). Jakarta: Salemba Humanika.

Aznil, F. (2019). PTPN V Riau hadapi masalah besar. Https://Detakindonesia. Co.Id/. https://detakindonesia.co.id/read/ detail/3656/ptpn-v-riau-hadapi-masalahbesar

Bangun, C. R. A. (2016). Peran departemen corporate communication dalam melakukan sosialisasi nilai perusahaan melalui media internal: studi darya varia laboratoria tbk. Jurnal UltimaComm, 8(2), 45-56. http:// ejournals.umn.ac.id/index.php/FIKOM/ article/view/881/683

Cornelissen, J. (2004). Corporate communications theory and practice. London: Sage Pubications Inc.

Doorley, J., \& Garcia, F. (2011). Reputation management. Perancis: Routladge.

Ganiem, L. M., \& Kurnia, E. (2019). Komunikasi korporat. Jakarta: Kencana-Prenada Media Group.

Gasing, S. S., \& Suryanto. (2016). Public relation. Yogyakarta: Andi.

Hadi, N., \& Kuswanto, A. (2019). Buruh ptpn $v$ diusir paksa dari tempat tinggal milik perusahaan, lantaran beroganisasi. Gagasanriau.Com. https://gagasanriau. com/news/detail/41561/buruh-ptpn-vdiusir-paksa-dari-tempat-tinggal-milikperusahaan-lantaran-beroganisasi

Humas PTPN V. (2019). PTPN V Riau targetkan sertifikasi iscc untuk seluruh unit pabrik. Https://Ptpn5.Com. https:// ptpn5.com/2019/11/ptpn-v-riau-targetkansertifikasi-iscc-untuk-seluruh-unit-pabrik/

J.Moelong, L. (2016). Metode penelitian kualitatif. Bandung: Remaja Rosdakarya.

Juwita, R. (2017). Media sosial dan perkembangan komunikasi korporat. Jurnal Penelitian Komunikasi, 20(1), 4760. https://doi.org/10.20422/jpk.v20i1.136

Kriyantono, R. (2012). Public relation \& krisis manajemen. Jakarta: Kencana Prenada Media Group.

Kuncoro, N. (2015). Government relations dan role model (strategi pt. perusahaan gas negara (persero) Jakarta dalam menjadikan DKI Jakarta sebagai kota gas (city gas) Di Indonesia). Ilmu Komunikasi UMS, 1(1), 1-16. http://eprints.ums.ac.id/38303/24/ NASKAH PUBLIKASI.pdf

Kusniadji, S. (2016). Strategi komunikasi pemasaran dalam kegiatan pemasaran Produk Consumer Goods. Jurnal Komunikasi, 8(1), 84-98. https://doi. org/10.24912/jk.v8i1.49

Miles, M.B, Huberman, A.M, dan Saldana, J. (2014). Qualitative data analysis, a methods sourcebook (3rd ed.). USA: Sage Publications. 
Nova, F. (2011). Crisis public relations: strategi public relations menghadapi krisis, mengelola isu, membangun citra, dan reputasi perusahaan. Jakarta: Rajawali Grafindo Persada.

Puspitasari. (2016). Komunikasi krisis mengelola dan memenangkan opini public (I, Ed). Jakarta: Libri.

Regester, M., \& Larkin, J. (2005). Risk issues and crisis management in public relations: a casebook of best practice (2nd ed). London: Kogan Page.

Ruslan, R. (2014). Manajemen publik relation dan media komunikasi (konsep dan aplikasi). Jakarta: Raja Grafindo.

Sagala, C., \& Chairuna, R. (2015). Analisis peran investor relations PT.Semen Indonesia. Journal of Business Ethics, 52(1), 1-26. http://lib.ui.ac.id/file?file=digital/20166/20416399-MK-Christiani Sagala.pdf
Siregar, B. P. (2019). PTPN V kembalikan lahan 2.800 Hektare ke Negara. Wartaekonomi. https://www.wartaekonomi.co.id/ read235263/ptpn-v-kembalikan-lahan2800-hektare-ke-negara

Sugiyono. (2015). Metode penelitian kuantitatif kualitatif $r \& d$. Bandung: alfabeta.

Van Riel, C. B. M., \& Fombrun, J. C. (2019). Essentials of corporate communication: implementing practices for effective reputation management. London dan New York: Routledge.

Wasesa, S. A., \& Jim, M. (2010). Strategi public relations. Jakarta: Gramedia Pustaka Utama.

Yanuar, D. (2017). Kekuatan integrated communication untuk membangun reputasi dalam menghadapi krisis. Jurnal Komunikasi Global, 6(1), 1-14. http:// jurnal.unsyiah.ac.id/JKG/article/view/9179 